\title{
Fotografi Pertunjukan: Fenomenena Tubuh dari Panggung menjadi Rupa
}

\author{
RY. ADAM PANJI PURNAMA ${ }^{1}$ \\ Jurusan Teater, Sekolah Tinggi Seni Indonesia Bandung
}

\begin{abstract}
Performace Photography: The Body Phenomenon from Stage to Physical. Performance photography has tried its best to capture the phenomena on stage. These two art mainstreams are completely different both from the subject and the objects. Performing art utilizes eyes and noses as the guidance to the feeling and meaningful body movements. Meanwhile, photography only utilizes eyes due to the still images it uses. Body in the performance is the amalgamation of physical body and spiritual body. The detachment from a daily life to act as others according to the performance demand makes a performance meaningful and atmospheric for the audience.
\end{abstract}

Key words: Fotografi Pertunjukan, Pertunjukan, Tubuh.

\section{Pendahuluan}

Pertunjukan baik teater maupun tari membutuhkan proses latihan yang cukup panjang untuk menjadi sebuah karya seni yang sempurna. Proses latihan dimulai dari pola gerak, pola lantai, sampai dengan pola dialog (kalau dalam pementasannya menggunakan dialog). Para aktor mencoba untuk mengungkapkan keinginan sutradara, begitu pula penari berusaha untuk mengungkapkan keinginan koreografernya Mereka harus menyesuaikan diri dengan tempat pementasan, seperti prosenium, arena, bentuk panggung khusus, serta dengan konsep artistiknya.

Pementasan karya akan membawa kesan yang dalam bagi apresiator bila pertunjukannya bagus, baik secara visual maupun dari dialog yang terdengar. Kesan dari pertunjukan akan menempel di benak apresiator, tetapi di lain waktu kemungkinan hilang tertumpuk oleh berbagai kegiatan. Dengan demikian, kesan pertunjukan pada diri apresiator lebih bersifat spontan, mudah hilang karena kegiatan sehari-hari.

Hasil kesan yang ditangkap secara spontan dalam suatu pertunjukan terasa sangat berbeda apabila hanya melihat hasil karya fotografer pertunjukan tersebut. Daya tangkap kamera foto memiliki perbedaan dengan daya tangkap mata manusia. Mata secara langsung dapat merekam seluruh ruang pertunjukan. Selanjutnya hasil tangkapan mata tersebut disalurkan ke otak dan bercampur dengan olah rasa sehingga dapat menangkap visual suasana yang dibangun oleh pertunjukan tersebut. Sementara kamera hanya dapat menangkap visual dengan diafragma yang cukup besar dan rana yang membuka lambat.

Hasil gambar ditentukan oleh pengalaman seorang fotografer. Gambar akan lebih terlihat lebih bernyawa bila fotografer terlibat secara langsung dalam proses garapan pementasan, terlebih jika fotografer sebagai pelaku seni pertunjukan. Fotografer akan lebih tahu tentang hal yang ingin disampaikan dalam pementasan tersebut, sehingga gambar yang dihasilkan dapat memancarkan ekspresi panggung. Fotografer juga berhak untuk mengekspresikan diri berdasarkan ekspresi pementasan.

Proses pemotretan pertunjukan yang biasa dilaksanakan oleh fotografer meliputi dua bagian pokok yaitu: (1) khusus sesi pemotretan, waktu dilaksanakan sebelum pertunjukan yang sebenarnya, dan (2) pemotretan pada saat pertunjukan berlangsung. Sesi pemotretan sebelum pertunjukan ini biasanya dibuat untuk keperluan dokumentasi serta publikasi. Fotografer dengan

\footnotetext{
Alamat korespondensi: Jurusan Teater, Sekolah Tinggi Seni Indonesia Bandung, Jln. Buah Batu No. 212, 08122182306,e-mail: adampanji@yahoo.com.
} 
pertimbangan dari penggarap bisa meminta posisi atau adegan tertentu untuk diambil gambarnya. Sementara pemotretan saat pertunjukan berlangsung, fotografer harus menyesuaikan diri dengan kondisi pertunjukan.

Seorang fotografer yang mengabadikan pertunjukan sebaiknya mengetahui terlebih dahulu bentuk pertunjukannya. Hal ini berkaitan dengan persoalan teknis, baik pencahayaan maupun komposisi. Pertunjukan kadang tidak berkompromi dengan fotografer, karena keduanya mempunyai keinginan dan daya ungkap yang berbeda. Kejelian dan kepekaan rasa serta penguasaan teknis baik terhadap alat yang dipergunakan maupun pencahayaan yang dipergunakan, perlu diasah terus menerus oleh seorang fotografer.

Fotografer pertunjukan berusaha semaksimal mungkin dapat menangkap fenomena yang terjadi $\mathrm{di}$ atas panggung/arena permainan. Memang, dua seni ini cukup berbeda baik dari materi maupun cara ungkapnya. Pertunjukan yang dinikmati secara langsung menggunakan mata dan telinga sebagai penuntun menuju perasaan. Sementara foto hanya menggunakan mata saja karena menjadi gambar yang diam. Gambar diam tersebut harus dapat menangkap esensi bangunan emosi pertunjukan tersebut, sehingga orang yang melihat gambar dapat pula menangkap rasa yang tertangkap oleh mata kamera. Dengan demikian, ketepatan bidikan mata kamera terhadap angle gerak olah tubuh menjadi suatu representasi penting bagi penafsiran makna hasil fotografi pertunjukan.

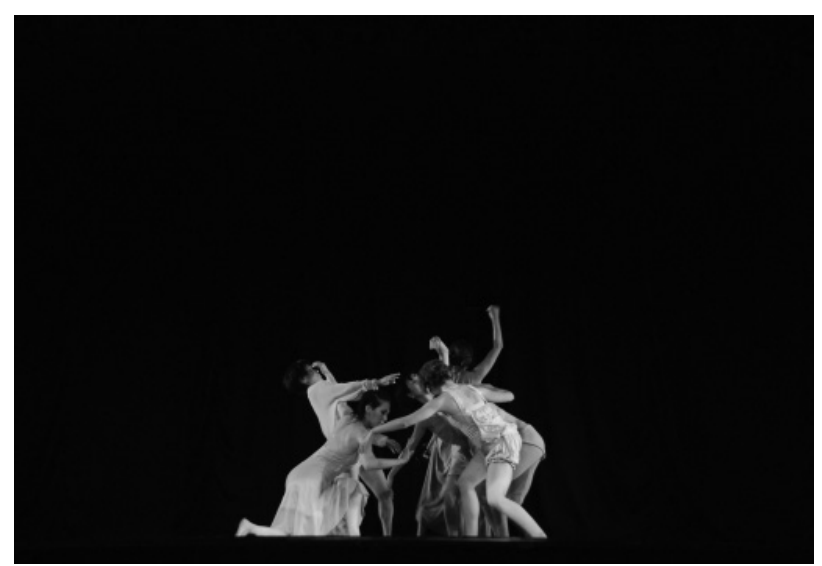

Koreografer: Kazco Takemoto, Jepang,

(Adam Panji, 2009)

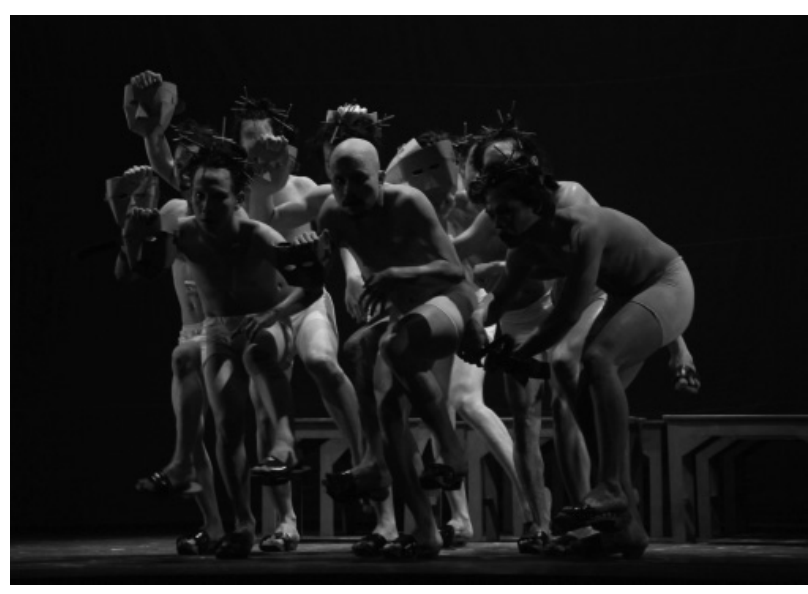

Tubuh Bedaya Tubuh", Sutradara: Tonny Broer, (Adam Panji 2009)

\section{Reinterpretasi Foto Pertunjukan}

Richard E. Palmer menerangkan bahwa hermeneutika adalah salah satu ilmu untuk menafsirkan. Hermeneutika berasal dari kata Yunani yaitu hermeneuien yang berarti menafsirkan, menginterpretasikan, atau menerjemahkan (Palmer, 2005:15-31). Pada awalnya ilmu ini untuk menafsirkan kitab saja. Namun, pendekatan yang dilakukan oleh Palmer berupa teks dalam pengertian kontemporer, bukan hanya ditujukan pada teks-teks suci, puisi, ataupun syair saja, tetapi bisa diterapkan pada seni pertunjukan dan seni rupa.

Memahami seni pertunjukan dengan hermeneutika harus mengedepankan juga paham tentang seni. Paham ini menempatkan estetika sebagai sesuatu yang memiliki nilai tersendiri pada sebuah karya seni, yang dalam kebenarannya tidak dapat dicapai oleh metode ilmiah (Jaeni, 2007: 32). Pertimbangan estetis ini juga yang mendasari seorang fotografer pertunjukan pada saat mengeksekusi kejadian.

Perbedaan yang didapat adalah interpretasi seorang fotografer akan berbeda pada saat melihat hasil foto pertunjukan. Foto-foto pertunjukan perlu dimaknai menjadi karya tersendiri. Berbeda dengan video yang memuat gambar bergerak ditambah suara, foto hanya visual beku yang mengandung makna.

Perlu penyusunan kembali foto-foto pertunjukan agar menjadi karya yang lebih dramatis dan mempunyai makna yang mendekati garapan awal sebagai seni pertunjukan. Karya foto pertunjukan harus dapat menceritakan kembali gambaran 
suasana yang bersifat narasi (narrative) dengan modal dari foto-tubuh pertunjukan. Secara leksikal, narasi berarti cerita atau kisah. Dalam kesusasteraan, narasi terbagi dua yaitu unsur intrinsik dan ekstrinsik. Intrinsik mengandung beberapa aspek yaitu peristiwa, tokoh, latar (setting), dan alur (plot). Relasi antarunsur tersebut membentuk kesatuan cerita. Bagian ekstrinsik adalah cerita terbangun atas gagasan dasar yang ingin disampaikan pengarang/pencipta dalam karyanya. Aspek yang terkandung pesan, amanat, kritik, nilai, yang disampaikan oleh pengarang/pencipta (Saidi, 2008: 22)

Narasi mengalami perluasan dan perkembangan makna. Kata ini tidak hanya dipakai dalam dunia kesusasteraan saja, tetapi mulai dipakai dalam berbagai hal. Pada ilmu filsafat, narasi diartikan logika atau paradigm zaman (grand narrative), yang cenderung diartikan sebagai wacana kekinian (Saidi, 2008: 23). Chris Baker (2009: 33) mengatakan sebagai berikut:

"Narasi merupakan bentuk terstruktur di mana kisah membuat penjelasan tentang bagaimana dunia ini. Narasi menawarkan kepada kita kerangka pemahaman dan aturan-aturan tentang bagaimana tataran sosial dikonstruksi dan dalam melakukan hal ini narasi menyediakan jawaban terhadap terhadap pertanyaan:bagaimana seharusnya kita hidup?"

Menurut Acep Iwan Saidi, hasil foto-foto pertunjukan khususnya foto-foto tentang tubuh manusia, menjadi sebuah karya baru yang bersifat narasi. Alasannya adalah kandungan emosi yang terekam dalam gambar, seperti yang diungkapkan oleh Suwardi Endraswara (2008: 42) sebagai berikut.

"Dalam situasi nyata, emosi atau perasaan timbul oleh suatu situasi yang aktual, yang dapat membangkitkan perasaan-perasaan cinta dan benci, hasrat dan keengganan. Timbul rasa gembira bila hadir sesuatu yang menyenangkan, dan akan timbul benci serta marah jika dihadirkan suatu kedengkian atau kejahatan."

Selain alasan di atas, alasan lainnya adalah peristiwa yang terekam sebagai pusat narasi disampaikan dengan bahasa gambar sehingga memunculkan pelaku peristiwa, relasi antartokoh yang membentuk makna, serta terbangunnya ruang dan waktu peristiwa. Dengan demikian, narasi gambar melalui olah gerak tubuh pemain akan mencapai suatu representasi yang utuh.

\section{Esensi Nilai Tubuh}

Secara fisiologis, tubuh terdiri atas kepala, tangan, badan, kaki, atau lebih rincinya bagian dari kepala, rambut, mata, hidung, telinga, mulut, gigi, lidah dan sebagainya. Tanganpun bisa terbagi lagi menjadi ruas lengan, telapak, jari-jari dan seterusnya. Badan pun demikian terdiri dari dada, perut, pundak, punggung, dan seterusnya. Jika diteliti lebih dalam lagi, di dalam tubuh terdapat organ-organ lain yang tersembunyi di bawah kulit dan yang terlindung tulang. Secara biologi memang hal tersebut yang tampak, tetapi ada hal yang tidak disadari bahwa tubuh juga berfungsi sebagai penanda sosial.

Pemenuhan fungsi sebagai penanda sosial, tubuh dapat menjadi penanda identitas. Pengenalan seseorang lebih mudah bila diingat dari bentuk wajah, gender, postur, dan tanda-tanda yang terlihat. Namun, bentuk luar tubuh menjadi tidak berarti bila jiwa yang berada di tubuh tersebut tidak ada, seperti sebuah patung atau mayat. Aristoteles (384-322 SM) berpendapat bahwa jiwa sebagai prinsip kehidupan dan merupakan hal yang istimewa dari tubuh yang hidup. Tubuh dan jiwa merupakan dua hal yang tidak dapat dipisahkan (Synnnot, 2007: 15).

Tubuh sebagai fenomena biologis sudah diketahui banyak orang melalui fungsi-fungsi bagiannya yang dipelajari sejak usia dini. Adanya daya yang menggerakkan kekuatan di dalam tubuh, membuat tubuh mampu mengungkapkan diri dan berkomunikasi dengan orang lain. Daya ini tidak terlihat dan tidak terdengar. Secara sadar nafas menjadi simbol bahwa ada roh atau jiwa yang bersemayam di dalam tubuh. Pergerakan tubuh juga dipacu oleh pergerakan jiwa dari seseorang untuk mengungkapkan rasa atau merespons sesuatu di luar tubuh (Dillistone, 2002; 40). Tubuh menjadi simbol bagi keanekaragaman, kekuatan, kelembutan, keindahan. Bagian-bagian tubuh tidak mementingkan diri sendiri, tetapi selalu saling mendukung, bekerjasama untuk mencapai sesuatu atau tujuan tertentu bagi kepentingan bersama.

\section{Pemaknaan Tubuh Mitis Manusia}

Manusia beranggapan bahwa ada kekuatan lain di luar tubuhnya yang menggerakkan dirinya dalam berbagai hal. Pemikiran tersebut menyatakan bahwa manusia bukan seorang individu yang 
utuh. Manusia masih diliputi oleh perasaan-perasaan takjub, terpesona dengan gejala-gejala atau peristiwa di luar dirinya yang mengendalikan kehidupannya. Manusia mengakui kekuatankekuatan tersebut mengendalikannya, baik secara individu maupun berkelompok. Manusia tidak dapat dipisahkan dengan benda atau alam, subjek dengan objek sehingga kekuatan di dalam dan di luar dirinya akan bersatu dan membentuk pandangan tentang keberadaan mereka. Dunia transenden yang mengendalikan tersebut biasanya diwujudkan dalam benda-benda yang membentuk penyimbolan para leluhur, dewa-dewa, ataupun simbol lainnya sebagai panutan dan pelindung mereka dalam melaksanakan kehidupannya (Van Peursen, 1988: 42).

Tubuh hanyalah wadah dalam lingkaran terbuka yang dapat dikendalikan oleh kekuatan lain di luar dirinya. Tubuh menjadi perantara atau ungkapan dari para leluhur atau pendahulu, dewadewa, juga dimungkinkan kekuatan alam yang tergambar dari perilaku baik pada saat beraktivitas sehari-hari ataupun pada saat upacara yang diadakan kelompok untuk mencari jawaban dari fenomena-fenomena kehidupan. Tubuh-tubuh tersebut belum mempunyai pengakuan secara individu, mereka selalu memakai kekerabatan atau sekelompok suku yang masih bertalian, sehingga secara eksistensi pribadi tidak muncul menjadi perorangan. Kekerabatan tubuh inilah yang menjadi kekuatan bersama dalam pengendalian hidup.

Dalam masa tubuh mitis ini, manusia bisa dibedakan antara hidup dan mati. Secara jiwa, manusia tidak dapat membatasi perbedaan itu. Persembahan-persembahan, kurban pada tempat tertentu, dianggap mempunyai kekuatan besar sebagai pengendali yang menjalankan upacara dengan memanggil para dewa agar dapat hadir di dunia ini. Manusia mempercayai bahwa tubuh yang telah mati, jiwanya akan tetap tinggal bersama manusia yang hidup dengan menempati pohon-pohon, benda-benda keramat, ataupun tinggal di badan manusia yang masih hidup (Van Peursen, 1988: 45). Alam juga dipercaya menjadi bagian dari dirinya, sehingga kekuatan yang bersifat manusia dan ilahiah lebur menjadi satu. Kaum adat yang mempercayai kekuatan ini, mempercayai adanya titisan dewa yang merasuk pada manusia.
Pada dasarnya, pemikiran mitis menjadi penuntun atau pedoman bagi manusia untuk tetap hidup dan merespon alam atau habitatnya agar terjadi keseimbangan. Kandungan mitos mengungkapkan kebaikan dan kejahatan, hidup dan mati, hukum alam, dosa dan suci serta beberapa tuntunan bagi kehidupan manusia dalam bermasyarakat dan memanfaatkan alamnya. Manusia dalam bermasyarakat menganggap mitos adalah jalan keluar pada saat mereka sudah tidak dapat memecahkan masalah dunianya.

\section{Pemaknaan Tubuh Dinamis Manusia}

Sejak manusia lahir, tubuh dilengkapi dengan jiwa atau nyawa. Manusia tumbuh secara bertahap mengikuti perkembangan organ tubuhnya, meliputi ukuran, berat, kekuatan, gerak, serta daya nalarnya menjadi ukuran usia dan pencapaian adaptasinya terhadap lingkungan. Hal ini yang membedakan dengan manusia mati yakni tidak tumbuh, kaku, karena tidak berjiwa lagi. Hal ini diartikan sebagai kefleksibilitasan manusia atau kelenturan manusia terhadap gerak kehidupan.

Manusia dapat menyesuaikan diri terhadap lingkungan kecilnya, mengenali orang terdekatnya, menyusu, mengunyah makanan, berpegangan sampai berjalan. Manusia mulai mengenal kedudukan dalam komunitas kecilnya, benda-benda dan fungsinya terutama yang berkaitan langsung dengan kebutuhan. Manusia selalu berpikir menciptakan sesuatu untuk memudahkan dalam memenuhi kebutuhan. Perkakas dibuat awalnya cukup sederhana dengan teknologi seadanya, demikian juga pengolahan makanan, pakaian, serta penggunaan tempat berlindung sebagai rumah. Interaksi tubuh juga terbatas pada kelompok kecil di antara mereka saja, karena mereka hidup dengan berkelompok.

Orang-orang Yunani, membuat patungpatung, lukisan-lukisan dewa-dewa dengan tubuh yang indah. Tubuh sangat dipuja, terutama pada zaman Lysistrata, para dewa dewi dibuat sebagai lelaki perkasa dan wanita cantik (Synnnot, 2007: 12). Perupaan orang-orang suci ini berkembang sesuai dengan budaya dan kepercayaannya. Demikian juga agama dan kepercayaan yang dibawa oleh para pendatang mempengaruhi bentuk selanjutnya dari perupaan. Keindahan bentuk tubuh dengan wajah yang memancarkan 
kedamaian menunjukan sikap sebagai pelindung bagi penganutnya.

Pada perkembangan kehidupan, manusia mulai membebaskan pemikiran dan tatanan hidupnya dari pemikiran mitis. Kesadaran tersebut mulai tumbuh sehingga manusia mulai dapat menentukan jalan hidupnya sesuai dengan keinginanannya meski masih pada batas bahwa manusia percaya adanya pengendali lain. Mereka mencoba menghidupkan para dewa atau leluhur mereka dengan gambar maupun benda lain yang menyerupai manusia. Gambar-gambar tersebut dibuat indah dan sempurna, menurut pemikiran pada saat itu. Tubuh yang gemulai, wajah yang memancarkan kelembutan serta beberapa simbol yang menandakan kesejahteraan dan kebaikan, dibuat oleh para seniman dengan cermat. Selama masih berfungsi, budaya tersebut akan tetap dipertahankan, tetapi bila sudah tidak sesuai lagi dengan kebutuhan masyarakat, maka akan ditinggalkan (Daeng, 2005: 87).

Perubahan kehidupan, ditandai dengan perubahan masyarakat yang pada awalnya kelompok kecilyang bersahaja menuju masyarakat rumit yang besar. Mereka sudah menetap pada satu tempat sebagai masyarakat pengolah tanah pertanian yang subur sepanjang sungai. Mereka juga sudah menyimpan hasil panennya bersama. Kelompok lain menjadi penggembala atau peternak hewan. Pengetahuan yang bertambah berkat pengalaman dari tahun ke tahun diturunkannya secara lisan (Calne, 2005: 89-91). Budaya pun berkembang mengikuti kebutuhan untuk menjalani hidup. Penemuan-penemuan perkakas untuk memudahkan pekerjaan, membuat mereka terus berpikir dan mencoba membuat dari bahan-bahan lain.

Tuntutan untuk berinteraksi antarsesama melahirkan simbol-simbol yang dimengerti oleh mereka. Simbol-simbol tersebut berupa bahasa, baik oral maupun sikap tubuh, tulisan, tuntunan agama, pemerintahan, dan aturan hidup. Budaya baru ini membentuk klasifikasi tersendiri di antara masyarakatnya. Para bangsawan menempatkan dirinya mempunyai kelas lebih tinggi, disusul para cendikia, saudagar, priyayi, dan yang terakhir rakyat jelata (Kuntowijoyo, 2006: 34). Penggolongan ini membentuk penyikapan tubuhtubuh mereka ketika berinteraksi dengan orang lain. Rakyat harus menunduk, menyembah hormat pada orang yang berstrata lebih tinggi.
Sementara para bangsawan membatasi diri untuk berinteraksi dengan orang yang bergolongan lebih rendah. Perilaku ini terlihat dari bahasa tubuh, yang kemudian semakin dilegitimasikan.

Menurut Paul Schilder, tubuh perlu pencitraan. Citra tubuh tersebut berkembang dimulai dari masa kanak-kanak yang menyadarkan bahwa dia memiliki tubuh yang dapat menampilkan laku dan tindakan secara sengaja dapat mempengaruhi perasaan dan tingkah laku orang lain. Citra tubuh meliputi ruang yang mengelilingi tubuh, setiap individu menghasilkan citra tubuh berbeda-beda tergantung pada jarak yang ia tempati antara dirinya dengan orang lain (Schilder dalam Cavallaro, 2004: 180-181).

Tubuh-tubuh dengan elastisitasnya terus mengembangkan diri, pengalaman para pendahulunya mendidik secara langsung maupun tidak langsung untuk mengatasi kehidupan. Tubuh-tubuh itu terus bereksplorasi, beradaptasi dari setiap gejala alam dan perubahan sosialnya. Pemberontakan pemikiran tentang dunia mitis, tuntutan pemenuhan kebutuhan untuk menuju kesejahteraan hidup membentuk tubuh-tubuh tersebut semakin berbeda. Hal ini dikarenakan oleh tuntutan dan pemenuhan pencapaian kebutuhan yang berbeda pula. Interaksi tubuh dengan tubuh lain juga semakin menipis, ruangruang gerak juga sudah mulai dibatasi dengan berbagai tuntutan lain yang lebih menekankan pada individualism. Kaum urban yang berlatar belakang tubuh dari budaya berbeda mengadu nasibnya dengan memaksakan beradaptasi dengan perkotaan dan kehidupan modern.

Seni yang biasanya menggunakan tubuh sebagai media juga bergeser menjadi media elektronik yang menyuguhkan berbagai macam kesenangan, impian, juga informasi. Tubuh para penikmat sudah tidak perlu bersusah payah mencari panggung atau gedung pertunjukan. Pengaruh ini menyebabkan pandangan bahwa tubuh lebih mempunyai harga bila bentuknya indah, menarik dengan asesoris dan pakaian yang membalutnya.

\section{Representasi Tubuh Dramatis Pada Kese- nian Rakyat}

Karya pertunjukan merupakan ekspresi yang mempertimbangkan artistik dan estetik. Setiap gerak dan bunyi sudah mengalami perenungan agar dapat mencitrakan keinginan senimannya. 
Tentu saja ekspresi tersebut sudah diatur, ditata, serta ditambah dengan berbagai elemen lain agar lebih kuat daya ungkapnya.

Pada seni tradisi, persepsi tubuh pertunjukan memiliki keunikan tersendiri. Gerak pada tarian bisa menceritakan sesuatu atau memerankan sesuai tokoh yang diperankannya seperti pada penari Cak. Awalnya para penari lakilaki yang memerankan Rama, Laksmana, dan lainnya mengenakan busana sederhana, atau bahkan hanya memakai selembar kain yang dicawatkan (Soedarsono, 1999: 20). Tubuh yang memposisikan diri sebagai peran utama akan berbeda gerak dan posisi tubuhnya dengan peran lainnya.

Kesepakatan tidak tertulis juga menjadi rujukan turun temurun untuk beberapa penokohan. Tokoh-tokoh raksasa, kera, putri, satria dan sebagainya pada tradisi mempunyai gaya gerak tersendiri untuk menggambarkan karakter serta emosi yang dimainkan. Sangat berbeda bila meninjau seni-seni kontemporer yang mulai membebaskan gerak dan penokohan tetap, karena tubuh-tubuh sudah membebaskan diri dari pakem. Penari kontemporer lebih mengacu pada bentuk dan keindahannya. Bentuk menjadi konstruksi imajinasi, aktivitas pikiran yang digambarkan dengan pertimbangan estetis (Santayana dalam Kutha Ratna, 2007: 82)

Pada pelaksanaan upacara adat yang memakai seni, terutama seni tari sebagai media upacara, posisi tubuh penari menjadi istimewa. Kedudukan ini dikarenakan penari menjadi wakil dari kekuasaan atau kekuatan demi kesuburan, keselamatan. Menurut Sumandiyo Hadi, hal ini disebut "supraorganik", sesuatu yang tidak teraba,

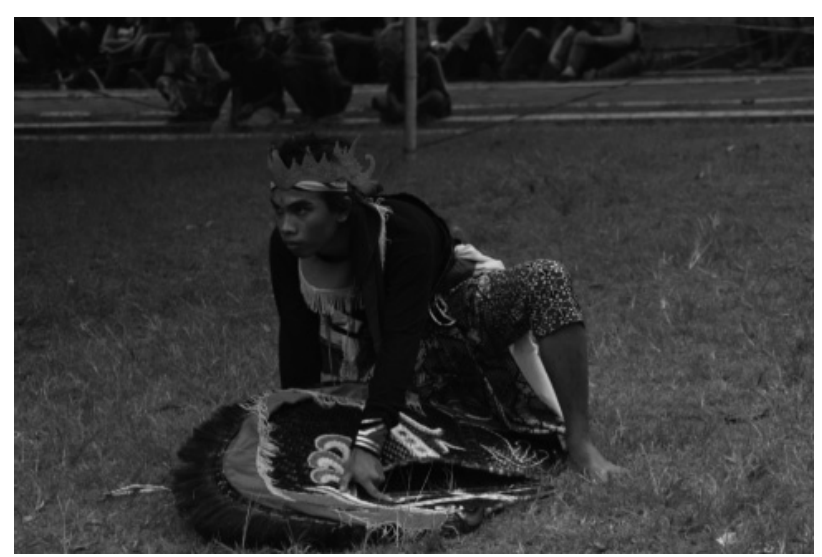

Jaran Kepang, Yogyakarta (Adam Panji, 2009) tidak nyata, tetapi tidak dapat segera ditunjukan fenomenanya (2005: 24). Sifat supraorganik ini sulit ditegaskan atau dijelaskan bila tidak memahami maknanya yang lebih dalam. Salah satu contoh posisi tubuh penari yang mewakili suatu kekuatan adalah seorang Shaman. Dia mengendalikan jalannya ritual yang dipercaya oleh masyarakatnya, mulai dari penentuan waktu, tempat, tata cara, sampai dengan perangkat yang harus disediakan untuk pelaksanaan. Seorang Shaman menempati posisi terhormat dan menjadi pusat perhatian. Masyarakatnya percaya dalam tubuh Shaman sudah menyatu kekuatan lain (ilahiah) dengan jiwanya, sehingga dia dapat menyalurkan kekuatan tersebut untuk keperluan masyarakat. Tubuh Shaman yang menyatu dengan kekuatan ilahiah tersebut sebagai perpanjangan tangan para leluhur, danyang, ataupun kekuatan yang lebih tinggi lagi yang biasanya dipercaya sebagai pelindung atau pengayom. Di beberapa daerah, Shaman juga memakai media tubuh lain untuk dimasuki oleh “jiwa” lain.

Contoh lain yang memakai tubuh sebagai wadah wadag tempat merasuknya para danyang adalah Seblang, pelindung desa Olehsari Banyuwangi. Penari yang dianggap masih suci dan belum dewasa, menjadi tokoh utama selama tujuh hari berturut-turut. Shaman atau Seblang tersebut disebut tukang kutug yang memimpin upacara untuk menuntun danyang memasuki si penari yang memakai omprok (mahkota yang dibuat dari pucuk daun pisang). Bersatunya tubuh penari dengan para danyang, dipercaya sebagai penolak bala. Bahkan omprok yang dipakai penari juga dipercaya mempunyai khasiat menyembuhkan penyakit, untuk pengasihan, dan dapat dipasang sebagai penolak energi negatif.

Demikian juga dengan penari kuda lumping dari kesenian rakyat di Yogyakarta yang mulai kerasukan dipercaya bersatu dengan kekuatan lain di luar tubuhnya untuk membentuk kekuatan lain. Penari tiba-tiba berada dalam keadaan tidak sadar sehingga dapat memakan pecahan bola lampu, padi, bunga, memecah kelapa, bahkan di beberapa tempat lain mereka memakan ayam hidup-hidup. Mereka menari sepertinya tidak merasa lelah, kadang berguling, atau merontaronta. 


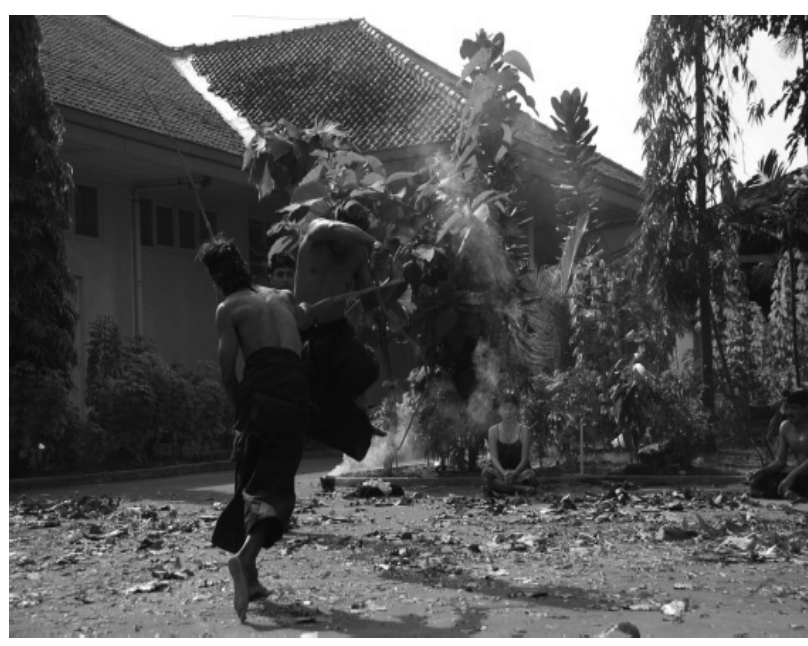

Upacara Tiban Trenggalek, Yogyakarta (Adam Panji 2009)

Lain lagi dengan daerah Trenggalek, sewaktu terjadi kemarau panjang masyarakat Trenggalek mengadakan upacara Tiban. Diiringi gamelan dan kendang dengan ritme tinggi, kaum lelaki beradu kekutan dengan saling memecut lawannya. Pecut yang digunakan terbuat dari batang lidi daun aren. Mereka saling melawan dan menghindar dengan bertelanjang dada, bahkan mereka cukup bangga bila terluka. Mereka percaya setiap pengorbanan darah yang menetes akan membuat tanah jadi subur dan hujan segera turun.

Beberapa contoh di atas memperlihatkan bahwa tubuh pada saat-saat tertentu di beberapa tempat masih dikendalikan oleh kekuatan lain yang dipercaya sebagai dewa, leluhur, atau hal lainnya yang mengendalikan makrokosmos. Tubuh hanya sebagai wadah jiwa, kita tidak bebas karena dituntun oleh alam, ataupun kekuatan lain pengendali kehidupan. Tubuh dapat menjadi media untuk dapat berkomunikasi dengan leluhur pada saat masyarakatnya mengalami suatu permasalahan yang tidak dapat dipecahkan.

Tubuh dalam pementasan atau pertunjukan merupakan gabungan tubuh fisik yang memperagakan laku dari tubuh ilahiah. Pelepasan keseharian dan menjadi peran lain dan berperilaku sesuai dengan tuntutan pertunjukan membuat sebuah pertunjukan mempunyai makna dan suasana yang ditangkap oleh penonton.

Pemotretan pada kesenian rakyat yang mempergunakan media seni pertunjukan tetap mementingkan sisi-sisi informasi penunjang seperti latar belakangnya dilaksanakannya kesenian tersebut, waktu pelaksanaan, masyarakat yang terlibat, tata cara pelaksanaan, urutan pelaksanaan, perlengkapan yang dipakai, serta tanggapan masyarakatnya. Hal ini menjadi penting karena perekaman tidak hanya bertujuan untuk mendapatkan gambar yang baik, tetapi juga mendokumentasikan kesenian tersebut dengan baik. Fotografer harus merekam dengan baik suatu kejadian yang menjadi informasi secara visual tentang peristiwa yang direkamnya termasuk salah satunya penyampaian tubuh mitis pada ritual kesenian rakyat.

\section{Penutup}

Foto pertunjukan tidak hanya menjadi dokumentasi pementasan saja, tetapi dengan keistimewaan dari pertunjukan serta penangkapan gambar maka foto-foto yang indah dan ekspresif tersebut dapat dimanfaatkan untuk mewujudkan karya lain yang tidak kalah menarik. Foto-foto yang dipilih adalah foto yang menunjukkan ekspresi tubuh dan mimik, tubuh-tubuh tersebut lebih mengungkapkan emosi dan menarik untuk diolah kembali dan disesuaikan dengan kebutuhan pewujudan karya.

Penyusunan foto dalam satu karya, dapat mengungkapkan adegan-adegan dengan gambaran suasana dan komposisi yang menentukan interpretasi apresiator. Pemanfaatan foto pertunjukan dalam sebuah karya seni, menjadi alternatif curahan ekspresi sebagai tindak lanjut dari perjalanan karya seni tersebut. Dengan demikian, foto-foto tersebut tidak berhenti pada kepingan CD ataupun tumpukan album saja, tetapi dapat melahirkan karya-karya lain yang berbahan pokok foto pertunjukan.

\section{Kepustakaan}

Barker, Chris. 2009. Cultural Studies. Yogyakarta: Kreasi Wacana.

Calne, Donald B. 2005. Batas Nalar. Jakarta: Kepustakaan Populer Gramedia.

Cavallaro,Dani. 2004. Critical and Cultural Theory. Yogyakarta: Niagara.

Daeng, Hans J. 2005. Manusia, Kebudayaan dan Lingkungan. Yogyakarta: Pustaka Pelajar.

Dillistone, F.W. 2002. The Power of Simbols. Yogyakarta: Kanisius.

Endraswara, Suwardi. 2008. Metode Penelitian Psikologi Sastra. Yogyakarta: MedPress.

Jaeni. 2007. Komunikasi Seni Pertunjukan. Bandung: Etnoteater Publisher. 
Kuntowijoyo. 2006. Budaya dan Masyarakat. Soedarsono, R.M. 1999. Seni Pertunjukan Indonesia Yogyakarta : Tiara Wacana. dan Pariwisata. Bandung: MSPI.

Kutha Ratna, Nyoman. 2007. Estetika Sastra dan Sumandiyo Hadi. 2005. Sosiologi Tari. Yogyakarta: Budaya. Yogyakarta: Pustaka Pelajar. Pustaka.

Palmer, Richard E. 2005. Hermeneutika. Yogyakarta: Synnnot, Anthony. 2007. Tubuh Sosial. Yogyakarta: Pustaka Pelajar.

Pustaka Pelajar.

Saidi, Acep Iwan. 2008. Narasi Simbolik Seni Rupa Van Peursen, C.A. 1988. Stategi Kebudayaan. Kontemporer Indonesia. Yogyakarta: Isacbook. $\quad$ Yogyakarta: Kanisius. 